УДК 339.1-339.9

JEL Classification M 31, F 20

Marina Kirnosova

PhD (Economics), Assistant Professor

Assistant Professor of Department of Marketing

Odesa National Polytechnic University (Odesa, Ukraine)

Anastasiia Zhekul

student in Marketing

Odesa National Polytechnic University (Odesa, Ukraine)

\title{
MODERN TRENDS ON INTERNET MARKETING IN THE INTERNATIONAL MARKET
}

The article considers modern trends in the development of digital marketing in the international market. The important aspects of the influence of information technologies on the change of human everyday life and activity of enterprises are highlighted. The significance of Internet marketing has been defined to meet the needs of the new generation of consumers. The analysis of the development of globalization and the emphasis on its transformation in the processes of glocalization. The basic directions of use of information technologies in marketing with their tendency for personification are determined. Analyzed effective tools for promoting products in the Internet, which have a significant development in recent years. Highlights of the main information and advertising technologies in the international market. A conclusion is made regarding the further transformation of marketing in connection with the rapid development of technologies, in particular, the development of the $5 G$ standard.

Key words: internet marketing, globalization, glocalization, international market, information and advertising technologies.

\section{DOI: 10.15276/mdt.3.2.2019.5}

Statement of the problem in general form and it's connection with important scientific or practical tasks. At the end of the 20th - at the beginning of the 21 st century, the main process of developing an international market - the globalization of the world economy. The national economies of the world are united into a single market system, where goods, information and capital have the opportunity to move freely, and ideas are freely distributed, improving and stimulating the development of modern institutions.

The rapid development of globalization were significantly influenced by the technical improvement of communication and transport, which make it possible to reduce the economic distance between the borders of the states. Thanks to accessing to the necessary information from any point of the planet in real time and the ability to quickly make decisions, modern telecommunications systems make it easier to organize international investment of capital and co-operate with marketing and production. In conditions of information integration of the world the country can borrow foreign experience of management, accelerate the process of creating new technologies.

(C) 2019 The Authors. This is an open access article under the CC BY license (http://creativecommons.org/licenses/by/4.0) 
The first source of globalization of such processes that existed only within the country begins is the management of financial transactions or the acquisition of higher education.

The second source of globalization - economic freedom and free trade outside the country, which limited the protectionist policy and made the cross-border trade liberal. As a result, barriers to trade in goods and services were eliminated and tariffs significantly reduced. Other measures to liberalize trade have increased the movement of capital and other factors of production.

Creation of transnational corporations has become the third source of globalization of market relations, including marketing, in which a certain share of production, consumption, export, import and income of the country depends on the decisions of international centers abroad of this state.

The Internet has changed human life and has helped to reach the global level of many companies. Searching for customers, promoting their products and services to different countries, selling products without the need for physical presence in foreign markets offers significant opportunities for the more secure and effective operation of international marketing. Potential buyers have access to purchasing goods at any time of the day. In addition, territorial restrictions are abolished. E-commerce displaces traditional trade. 60\% of transactions are carried out using devices, the Internet, etc. Only 40\% comes from purchases by cash in stores [1].

Analysis of the latest research and publications, which initiated the solution of this problem and on which the author relies. Internet marketing is growing fast. It is becoming one of the main tools for product promotion, including in the international market. Significant contribution to his research was made by F. Kotler, R. Wilson, W. Henson, MA Oklander, T.O. Oklander, O.I. Yashkina SM Ilyashenko, VP Pylypchuk, IV Boichuk, E.V. Kricavsky, L.O. Ligonenko, O.K. Shafaluk. However, the unresolved part of the overall problem remains the rapid adaptation of marketing to the opportunities provided by information technology in the international market.

Formulation of the purpose of the article (statement of the problem). The aim of the article is to highlight the current trends in digital marketing in the international market.

Statement of the main material of the research with full justification of the scientific results obtained. The fast development of technologies, including information, changes the human way of life and the managerial-organizational and production aspects of the work of economic entities. Such processes are accelerating and require enterprises to adapt quickly to ensure their competitiveness.

B. Terkel introduces a new term "instant generation" - these are young buyers who have grown up with the immense need of digital technology and do not know how to function in an analog environment, which does not immediately respond to every one of their bosom [2; with. 37]. These consumers are no longer ready to wait for what they want, they want to get it immediately. In addition, their reaction to purchasing goods or receiving services is also instantaneous in the form of positive or negative feedback in social networks.

The number of Internet users in 2018 amounted to 4,021 billion, an annual growth of 7\%. The number of social networking users in 2018 was 3.196 billion, an annual growth of $13 \%$, and a daily increase of 11 people. Owners of mobile phones in 2018 were 5.135 billion, each year their number increases by $4 \%$. [3]

Globalization is becoming one of the most important factors influencing the further development of human society and covers all spheres of human activity: economy, science, security, education, environment, social sphere, politics, culture, etc. At the same time, information technologies at the global level lead to the creation of a single world information space. 
Globalization is reflected in the economy of all countries of the world. It affects the production of goods and services, the use of manpower, investment, technology and their distribution from one country to another. All this affects the efficiency of production, productivity and competitiveness. It is globalization that has exacerbated international competition.

Companies in almost all countries of the world are directly involved in the global business. In order for the company to be able to enter the international arena, it must take into account the real world market situation, which includes the definition of needs and demands of consumers and determine the possibilities for changing them in the future. It is this knowledge that is provided through the implementation of international marketing. The implementation of international marketing firms helps to identify the needs and the ability to meet these needs in the best possible way.

By realizing of international marketing, the company strives to achieve its goals first of all. The main goal of all commercial companies is to maximize profits. In addition to the main goal, there are secondary ones, which may include:

- access to a new markets;

- increasing of sales volumes;

- conquest of higher positions in target markets;

- providing more favorable conditions for industrial and commercial activities;

- providing competitive advantage;

- reduction of production costs per unit of goods;

- formation of positive image and commitment of consumers to the goods and services of the firm, etc.

When using international marketing, the firm implements a systematic approach to management with a well-defined goal, which is detailed by a set of measures aimed at its achievement. To do this, she carries out the following:

- defines the needs for each particular product;

- produces goods that are most appropriate to the identified needs;

- provides the promotion of goods to the target market using a complex of communications, which includes advertising, public relations, personal sales and their promotion;

- finds an opportunity to enter foreign markets;

- ensures the delivery of goods in the required quantity, at a given time and place;

- sets the price acceptable to the buyer and ensures the receipt of the necessary profits by the seller.

So, the company, knowing the real needs and determining the possibility of their satisfaction, using the four main tools of the marketing complex, offers on every foreign market the goods in the required quantity and assortment, at an affordable price, in a certain place and at a given time.

The process of globalization of the market has accelerated in recent decades, precisely because of the use of modern technologies in international marketing, when capital markets, technologies and goods, as well as labor, became increasingly interconnected in a multi-layered network of multinational corporations. While some international corporations focus on the traditional trading sector, most international firms advocate the restructuring of industry in most developing countries by creating new technologies in various industries.

Modern global corporations operate predominantly in information and financial markets, unlike previously-operating corporations that did not have these capabilities. The formation of a single global financial information space takes place through the global unification of these markets. Accordingly, the growth of the influence of international 
corporations and bodies regulating their activities - international economic organizations and structures - is very fast.

Through the study of the global economy model, it has been determined that 147 transnational corporations have an impact on $40 \%$ of total world income. The analysis of the interconnections of transnational corporations, which is only 43 thousand, has revealed that only a small number of financial corporations has a disproportionately large impact on the international economy and the world market. The researchers found 1,318 copans with the largest number of indirect links, controlled $20 \%$ of world income directly, and, because of ownership of shares in the share capital of the largest international companies, have $60 \%$ of world income. These companies are owned by 147 multinational corporations, most of which are financial institutions. [4]

Together with the processes of globalization, there is a phenomenon of globalization, which combines global and local and points to significant local differences between different cultures. The post-global stage of development of mankind with the slogan in business has come - "to think globally, but to act locally" [5, p. 109-124].

In international marketing it is expedient to use personalization not only products and services, but also elements of Internet marketing in their promotion. This affects the ability to highlight the company's products among many offers and increase consumer loyalty to it.

In modern society, international marketing must be based on new concepts, ideas, and creativity of producers. And also be as close as possible to the consumer, having analyzed the traditions, the specifics of consumption of other countries in which this product comes true. Fast-moving information technology has entered a new level of development, at the moment new technologies are in place in places of marketing activity in which they were not available before.

At the moment, all international corporations are actively using information technology. That allows direct contact with consumers from different countries of the world, to identify needs and even have an impact on the masses.

At this stage, the fourth concept of Internet marketing with the main strategy of struggle for the consumer develops. For her is characterized by the rapid development of Internet technologies, social networks, an individual approach, the use of chat bots, etc. [6, p. 55]. The main areas of information technology use in digital marketing are as follows (Fig. 1).

Most TNCs focus on marketing in social networks, that is, because of their advertising on the Internet, they promote their products, create their own websites, communicate with consumers. Website promotion in social media is a set of activities aimed at attracting visitors from social media: blogs, social networks, and more.

Innovative ways of promotion products on the Internet, which have been quickly developing in recent years:

1. Non-standard advertising media

1.1. Promotional games

1.2. Virus rollers

2. Promotion of the site in social networks

2.1. Social Networking Optimization (SMO)

2.2. Marketing in Social Networks (SMM)

2.3. Advertising in social networks (Ads)

3. Internet Exhibitions

4. System of interaction with sellers

5. Web conferences

5.1. Podcasting

5.2. Web seminars 


\begin{tabular}{|c|c|c|c|c|}
\hline \multicolumn{5}{|c|}{ Main directions of information technology development in marketing } \\
\hline $\begin{array}{l}\text { Marketing information } \\
\text { systems }\end{array}$ & $\begin{array}{l}\text { Software tools and } \\
\text { automation of } \\
\text { marketing activities }\end{array}$ & Internet Marketing & $\begin{array}{l}\text { Mobile } \\
\text { marketing }\end{array}$ & $\begin{array}{l}\text { Marketing in social } \\
\text { networks }\end{array}$ \\
\hline $\begin{array}{l}\text { Interstate information } \\
\text { and marketing centers }\end{array}$ & $\begin{array}{l}\text { Customer relationship } \\
\text { management systems }\end{array}$ & $\begin{array}{l}\text { Contextual } \\
\text { advertising }\end{array}$ & SMS-services & $\begin{array}{l}\text { Social networks } \\
\text { monitoring }\end{array}$ \\
\hline $\begin{array}{l}\text { Regional information } \\
\text { and marketing centers }\end{array}$ & $\begin{array}{l}\text { Marketing } \\
\text { intelligence }\end{array}$ & $\begin{array}{l}\text { Search optimization } \\
\text { and promotion }\end{array}$ & $\begin{array}{l}\text { Voice } \\
\text { Interactive } \\
\text { Services } \\
\end{array}$ & Teaser advertising \\
\hline $\begin{array}{l}\text { Sectoral marketing } \\
\text { information systems }\end{array}$ & $\begin{array}{l}\text { Marketing } \\
\text { automation }\end{array}$ & $\begin{array}{l}\text { Marketing research } \\
\text { on the Internet }\end{array}$ & $\begin{array}{l}\text { Wireless data } \\
\text { transfer } \\
\text { protocols }\end{array}$ & $\begin{array}{l}\text { Promotion in social } \\
\text { networks }\end{array}$ \\
\hline \multirow{2}{*}{$\begin{array}{l}\text { Geoinformation } \\
\text { marketing systems }\end{array}$} & \multirow{2}{*}{$\begin{array}{l}\text { Automation of } \\
\text { marketing commodity } \\
\text { turnover }\end{array}$} & Viral advertising & & \\
\hline & & Email marketing & & \\
\hline
\end{tabular}

Figure 1 - Main directions of information technology development in marketing

Site promotion in social media can be divided into three branches - site change itself (SMO), marketing in social media (SMM), social advertising (social advertising).

SMO (Social Media Optimization) - translated from English means site optimization for social networks. In other words, this is a set of activities that need to be conducted on the site to effectively promote social networks.

SMM (Social Media Marketing) - The use of social platforms as channels for promoting the brand and solving other business tasks. In the SMM, the focus is on the social platforms itself.

Seeing the increasing popularity of social networks it becomes more appropriate to advertise your product or to inform the consumer exactly there. In 2018, the social network Facebook accounted for 2.2 billion consumers, Pinterest - 200 million, Spotifies - 170 million, Netflixes - 125 million [1]. At the moment, social advertising ("Social Ads") uses the user profile information and places ads for him that suits him exactly.

Promotion in social networks has a number of significant advantages over other methods of Internet marketing. Among these, the first thing to consider is the effect of placing links to the company's website. Advertising in blogs on famous sites can give much more than links on the main pages of the company's websites.

Internet exhibitions are one of the most modern ways of communicating with the seller of goods or services with their potential client. This new communication tool most often uses multi-sectoral small and medium enterprises. The company spends much less on this kind of exhibition than the traditional exhibition, and the target audience remains unchanged in quantitative terms. The virtual stand of any online exhibition is always available for potential customers and partners, and the time of the exhibition itself is unlimited. Unlike the virtual exhibition website, the whole group of thematically identical companies, and by definition better known to visitors to the network, differs from the site of the company itself.

Promotional games are a new but usefull and effective way of marketing. The success of promotional games in marketing is the ability to create an interesting game with a plot that is echoed with business or aimed at a promotional campaign or an advertising campaign. Actually, games with a user-friendly interface attract people who are already interested in the theme of the company-developer. In addition, during a game, a person is one way or another interested in what is happening in the game. This influence is used by the company to advertise its product or service. Promotional games help to establish contact with consumers, build a 
long-term brand awareness campaign and make the site more attractive. The use of a system of incentives or prizes motivates players to return to the game - it contributes to the formation of an audience of regular site visitors - potential consumers of products. This practice in marketing gives an effect at a relatively low cost of advertising and is recommended for business of any scale as a component of the company's major marketing activities.

Viral marketing - is the impact on the target audience of consumers, the promotion of advertising of goods and services is reflected at the expense of the target audience, which voluntarily engages in the dissemination of information about the subject of marketing. This advertising communication, so affects a person that he is "infected" by the idea and deliberately or consciously distributes information about the product, service, and it becomes active its advertising carrier.

One of the promising methods of promotion is Vendor Relationship Management (VRM) - the system of interaction with sellers. Such systems combine the needs of the buyer and the seller's offerings, anonymously inform sellers about the needs of a particular buyer.

One of the most important roles in distributing products in the market are web conferencing, web training.

A web conference means online meetings or online presentations, in which each participant is on a computer, and the connection between them is maintained on the Internet through the communication application installed on the computer Every participant's computer, or through a web application.

During the web training, one or more newsmakers work on site visitors. It can significantly increase the attendance of the site presence in the online conference of a wellknown person. By conducting conferences on actively visited resources, you can tell potential customers about manufactured goods and services to improve the image of their organization.

The release of Arrlé's new generation of iPod players has led to the emergence of a new type of broadcast. Along with musical broadcasts, the copyright broadcast service, called "Podcasting", appeared. Podcasting and webcasting are the creation and distribution of audio or video transmissions on the network, with a certain theme and periodicity of the publication. "Podcast Terminals" allow each user to download records from their own software releases. In a sense, "podcasts" are a sound alternative to text blogging. Many firms use this kind of gear, trying to reach their audience by distributing content on demand for mobile devices.

One of the most promising areas in the field of online sales is the transfer of a social graph (social interactions among users in social networks) between social networks (Portability of the Social Graph). At the moment, having registered in the new social network, the user must separately add their contacts. It is assumed that his social graph (certain social data and interaction with other users on the Internet) will be able to separate from social networks and will be stored in a separate database. Users will be able to interact as part of their network on static sites, the social graph will be transferred to simple web sites.

Google already offers its users to sign up for the Google Social Graph API. The API only provides addresses of public pages on the Internet and public information about the links between them. The API does not have access to restricted information, such as personal profiles and websites that are open to friends only.

Email marketing, that is, the ability to create mailings to the customer's mailbox is still a demand-driven and effective tool for promoting products. It is constantly evolving towards more personalization, interactivity and effective content creation. Now, in order to increase profits, TNCs take into account new technologies, trends, ideas and implement them through link creation services.

You can consider the following new trends for e-mailing: 
- personalized e-mail communication with customers of the retail network. A running loyalty program on cards in offline stores allows you to collect customer purchase data in a CRM system, and CRM integration with the distribution service helps to send a copy of checks by email with cross-sell and up-sell offers, a personal discount, tips on how to use the purchased goods and promotions at a point of sale, based on shopping history, at the point of sale where the customer usually makes purchases. Thus the company can directly communicate with the buyers of their goods;

- digital models of products delivered with e-mail. Very often the email channel is used as a means of delivering goods to the buyer: tickets to events, museums, aviation and rail tickets, and more. The presence of scanned codes allows you to use only a mobile phone to skip;

- Real-time personalization / updating of the content of the sent message. When the subscriber opens the email, the content may be updated depending on the goods viewed before, the city in which the client is located, the time of day etc. This makes email communication even more interactive and effective than before;

- use of traditional offline communication channels for attracting subscribers. Due to the widespread distribution of smartphones, it is possible to stimulate subscriptions not only online, but also in offline channels: TV, radio, outdoor advertising, for example, posters with QR-code linked to the subscription page that can be placed in the subway or retail outlets. sales.

A great contribution to the increase of the client base can carry subscriptions at sales places. More retailers are offering to place an order on the missing goods in the store through online terminals. It helps to collect e-mail addresses when ordering, helps to increase sales of the offered product and increase consumer loyalty:

-visualization of consumer data. Marketers have the need for a more comprehensive and detailed analysis of their customer base. The number of data increases, so their convenient access to them is necessary for their convenient work. On this basis, new reports appear in the interface for mailing platforms, linking eMaMail marketing data with other data sources integrated with the mailing service. Yes, Ofsys, integrated with Google Analytics, displays data on the number of orders, average check and turnover from each mailing list.

In addition to the reports, the interface of the platforms may appear entire interactive maps that visualize different data, average consumer income, the area of residence, the location of retail outlets next to him, etc. This helps to initiate further purchases in stores, plan the shares for a specific region [7];

- E-mails based on customer geolocation data. Using consumer location data allows you to customize the eMail campaign based on the client's local time. Thus, consumers from different regions have equal opportunities to take part in promotions.

The communication technologies are rapidly developing in the field of international marketing, a lot of services were created for the current state of the information profiling of the consumer, and the identification of the specific needs of the target consumers.

Among the examples of the introduction of the latest information and advertising technologies in the global sphere are:

1. Consumer-oriented marketing. After acquiring Atlas's advertising platform in Microsoft, Facebook restarted it as a system for tracking consumers' paths before entering into an agreement and made it an effective advertising technology tool [8]. Like the DoubleClick (Goolge) solution, Atlas is a platform that can display ads designed to create marketing campaigns, track the interaction with the brand and purchase path, and use digital advertising technology.

2. Modified payment systems and modern advertising technologies. PayPal, having separated from eBay, has opened new horizons for development and has been able to compete with other payment services and Apple [9]. The Touch ID (Apple) and Alipay (payment service 
of the Chinese company Alibaba, an e-commerce company) built into some smartphones do not allow PayPal to maintain leadership without introducing new technologies.

3. Major advertising technologies in the integration of television and mobile interactive channels. Delivery Agent has contracted with news stations, leading teleconnects and cable channels for the purpose of providing its platform ShopTV (service for the purchase of goods from TV programs) with mobile applications. That is, the Delivery Agent integrates shopping, television and mobile interactive channels with the help of modern technology. In order to improve the quality of media shopping, the Delivery Agent also entered into a contract with Sony for integrating ShopTV with their SideView extension (mobile TV management application). The Patented Context Delivery Agent database identifies products that are relevant to viewing the channel, transmission, hero, episode, stage, or advertisement, and displays them in the app, allowing viewers to make a purchase. The partnership with Sony will help improve the automatic content recognition (ACR) technology, which, according to the representatives of the Delivery Agent, is critical for the development of the TV commerce. TV networks and advertisers have integrated their programs with what is a digital fingerprint of their finger, when the current television is interacting with a mobile device [10]. Retailers also have the opportunity to display the order form of their product when the viewer views his ad.

4. Smartphones facilitate the use of bonuses for loyalty. Until recently, if the coupon / gift coupon was on the consumer on a smartphone, he could not use it in the store: the sensor did not scan the barcode from the screen of the mobile device. However, a new technology has now been introduced that allows you to use the promo code directly from your mobile device. On modern scanners are installed optical sensors, which can read barcodes from the screen of smartphones.

Conclusions from this research and prospects for further developments in this area. Internet marketing tools provide an opportunity to reach the global level even for small businesses, search for target market segments outside the country, increase market share and increase profits. And all this with the optimal marketing budget. The Internet erases the boundaries between countries, but to succeed using the new information technologies, we need to conduct a thorough analysis, which should precede their use. Marketers should not assume, but precisely know, that the introduction of innovations will improve the purchasing experience. Consideration should be given to the aspects of globalization and the need for an individual approach to the promotion of products and services in the international market. This is a significant factor in the competition. Information technology is constantly being refined and innovative solutions are emerging. However, their distribution in the world is not uniform. What has long been used in developed countries, in others, can only be embodied. When entering other markets, it is expedient to analyze the possibilities of using digital technologies and consumer behavior in dealing with various Internet marketing tools.

At the forefront are the possibility of personalization of Internet marketing tools through the receipt of data about the consumer, his social graph, geolocation. In turn, consumers become easier to make purchases using information technology of their smartphone, tablet, computer. It's a quick search for products, online design and purchase at any time, including overseas online stores, the use of bonuses and payment from a smartphone in regular stores.

Digital marketing is transformed with the development of information technology. Ukrainian mobile operators have only switched to the 4G standard, and a gradual introduction of the next $5 \mathrm{G}$ standard in the world is expected to be implemented and distributed. Over broadband Internet access will again affect the means of consumer interaction. The use of new trends in digital marketing and personalization and adaptation to the process of globalization are among the most important aspects of the company's operations on the international market. 
1. Myronova, N., \& Tretiak, Ya. (2018). Internet-trendy 2018: chomu na pershyi plan vyishly zminy, mozhlyvosti ta vidpovidalnist [Internet trends 2018: Why changes, cpportunities, and responsibilities come first]. https://mind.ua Retrieved from https://mind.ua/publications/20185562-internet-trendi2018-chomu-na-pershij-plan-vijshli-zmini-mozhlivosti-ta-vidpovidalnist (in Ukrainian)

2. Terkel, B. (2018). Use pro nykh [All about them]. Dnipro: Monolit. (in Ukrainian)

3. Korolov, Ye. Analityky narakhuvaly 4 mlrd korystuvachiv internet [Analysts have counted 4 billion Internet users]. https://techtoday.in.ua Retrieved from https://techtoday.in.ua/news/analitiki-narahuvali4-mlrd-koristuvachiv-internetu-90207.html (in Ukrainian)

4. 50 korporatsii, yaki keruiut svitom [50 corporations that run the world]. https://www.unian.ua Retrieved from https://www.unian.ua/world/558686-50-korporatsiy-yaki-keruyut-svitom-spisok.html (in Ukrainian)

5. Pollifroni, M. (2006). Globalization and Glocalization: an Epistemological Analysis from Business. Economics Economia Aziendal, no. 3, pp. 109-124.

6. Bochko, O.Yu. (2018). Evoliutsiia rozvytku kontseptsii internet-marketynhu [Evolution of the development of Internet marketing concepts]. Proceedings from MIIM '18: III Mizhnarodna naukovopraktychna konferetsiia "Marketynh $i$ tsyfrovi tekhnolohii" [The Third International Scientific and Practical Conference "Marketing and digital technology"], 55-56. Odesa: TES. (in Ukrainian)

7. Dannye po tranzaktciiam email podpischikov teper dostupny v Ofsys blagodaria integratcii s Google Analytics [Subscribers email transaction data is now available in Ofsys thanks to integration with Google Analytics]. https://www.cossa.ru Retrieved from https://www.cossa.ru/155/93616/ (in Russian) 8. Reklama pridet v Microsoft Outlook [Ads will come in Microsoft Outlook]. https://www.sostav.ru Retrieved from https://www.sostav.ru/publication/reklama-pridet-v-microsoft-outlook-b-xbox7048.html (in Russian)

9. eBay i PayPal ofitsiino vidokremylys odyn vid odnoho [eBay and PayPal are officially separated from each other]. https://news.finance.ua Retrieved from https://news.finance.ua/ua/news/-/354816/ebay-ipaypal-ofitsijno-vidokremylysya-odyn-vid-odnogo (in Ukrainian)

10. Delivery Agent Embeds ShopTV with Sony. www.multichannel.com Retrieved from https://www.multichannel.com/news/delivery-agent-embeds-shoptv-sony-390230 (in English)

Кірносова М.В., канд. екон. наук, доцент, доцент кафедри маркетингу, Одеський національний політехнічний університет (Одеса, Україна)

Жекул А.А., студент кафедри маркетингу, Одеський національний політехнічний університет (Одеса, Украӥна)

Сучасні тенденції Інтернет-маркетингу на міжнародному ринку.

B статті розглянуто сучасні тендениії розвитку ичифрового маркетингу на міжнародному ринку. Виділено важливі аспекти впливу інформаційних технологій на зміну людського побуту та діяльності підприємств. Визначено значущість інтернет-маркетингу для задоволення потреб споживачів нового покоління. Проаналізований розвиток глобалізації та зроблено акиент на ї̈ трансформації в прочеси глокалізації. Визначені основні напрями використання інформаційних технологій у маркетингу з їх тенденцією до персоніфікаиії. Проаналізовані ефективні інструменти просування продукції у мережі інтернет, що мають значний розвиток останні роки. Виділено основні інформаційно-рекламні технології на міжнародному ринку. Зроблено висновок щцодо подальщої трансформації маркетингу у зв'язку зі стрімким розвитком технологій, в частковості розробки стандарту $5 G$.

Ключові слова: інтернет-маркетинг, глобалізація, глокалізація, міжнародний ринок, інформаційно-рекламні технології.

Received to the editor April 26, 2019. 